\title{
КУЛЬТУРНО-ИСТОРИЧЕСКИЕ ПРЕДПОСЫЛКИ ФОРМИРОВАНИЯ МЕНТАЛИТЕТА СОВЕТСКОГО НАРОДА
}

\section{CULTURAL AND HISTORICAL BACKGROUND OF THE FORMATION OF THE SOVIET PEOPLE MENTALITY}

\section{A. Kamianets} I. Kovaleva

Summary: The paper is devoted to the basic mental characteristics of the Soviet people as the development of cultural and historical traditions of the Russian super-ethnos. The connection of traditional religious-communal way of life of the Russian people with the way of life of the Soviet people is considered. Among the revealed features of the Soviet people mentality, special attention is paid to its most stable characteristics, which have not lost their significance for a better understanding of the problems of contemporary Russian society. A comparison is also made of the traditional Russian mentality, which developed in the Soviet period and the peculiarities of the European peoples' mentality. Of particular interest to researchers of the Soviet civilization is the analysis of the influence of the Russian people mentality on the character of the 0ctober revolution and the choice of the historical path of development by the peoples of Russia in the Soviet period. Important for studying the problems and contradictions of modern Russian society is also the selection of those characteristics of the Soviet mentality that have not lost their significance in the conditions of our time.

Keywords: mentality, nation, culture, community, tradition, society, communism.
Каменец Александр Владленович

Д.культурологии, профессор, Российский государственный сочиальный университет (Москва) kamenez.a@rambler.ru

Ковалёва Инна Алексеевна

Аспирант, Российский государственный социальный университет (Москва) in_kov19@mail.ru

Аннотация: Статья посвящена основным ментальным характеристикам советского народа как развитию культурных и исторических традиций российского суперэтноса. Рассматривается связь традиционного религиозно-общинного уклада русского народа с образом жизни советских людей. Среди выявляемых особенностей менталитета советского народа особое внимание уделяется его наиболее устойчивым признакам, которые не потеряли своего значения для лучшего понимания проблем современного российского общества. Проводится также сопоставление традиционной российской ментальности, получившей развитие в советский период и особенностей менталитета народов европейских стран. Особый интерес для исследователей советской цивилизации представляет анализ влияния менталитета русского народа на характер Октябрьской революции и выбор народами России исторического пути своего развития в советский период. Значимым для изучения проблем и противоречий современного российского общества является также выделение тех характеристик советского менталитета, которые не потеряли своего значения в условиях нашего времени.

Ключевые слова: менталитет, народ, культура, общинность, традиция, общество, коммунизм.

При этом упускается из виду тот факт, что сама Советская власть выражала волю и чаяния большинства членов общества, демонстрируя известное правило: «каждый народ заслуживает той власти, которая им руководит». Конечно, у этого правила бывают и свои исключения. Но, если иметь в виду, что советский период развития нашего общества был достаточно продолжительным и отличался преобладающим единодушием народа в отношении к существующему политическому режиму, то вряд ли можно считать случайностью поддержку последнего большинством советских граждан.

При этом остается достаточно дискуссионным для современных исследователей советского общества вопрос: «Явился ли менталитет советского народа естественным продолжением его досоветской истории или он стал результатом только специальной идеологической обработки массового сознания жителей России?» Сама постановка такого вопроса не случайна. Она означает распространенность исследовательской позиции, 
не усматривающей в советском периоде нашей истории реализации каких-либо серьезных исторических предпосылок для создания социалистического государства, рассматривая последнее преимущественно как результат «большевистского переворота». Очевидно, что в этой ситуации стремление изучать советский менталитет как результат влияния определенных объективных и субъективных факторов становится одной из актуальных исследовательских задач.

\section{Методика}

Исследование менталитета советского народа, определившего внутреннюю логику и приоритеты развития построения социализма в нашей стране, необходимо осуществлять в соотнесении с предыдущим периодом отечественной истории (историко-генетический подход), а также как проявление объективных социальных закономерностей, проявляемых наиболее ярко при тех или иных отклонениях в общественном развитии от некоторой общепринятой «социальной нормы» $[3,14,16,19]$.

Представляется перспективным для изучения этих закономерностей использовать достижения одного из ведущих исследователей советской цивилизации, всемирно известного логика и писателя А.А. Зиновьева, предложившего методы «логической социологии» $[9,18]$.

В качестве основного объекта изучения этот исследователь предложил выделять те или иные объединения людей, названные им «социальными объектами». При этом важно, чтобы эти объединения оставались устойчивыми. Их устойчивость обеспечивается единой идеологией, которая не обязательно должна соответствовать реальности или познанию таковой. Она выполняет сугубо интегративную функцию.

В советском обществе такой идеологией стал марксизм, который в качестве исторического наследия европейской марксистской мысли стал своеобразной мифологией, формирующей менталитет советского человека. Аналогичную интегративную функцию выполняет господствующая идеология в капиталистических странах, что позволяет делать вывод о наличии этой функции как объективной социальной закономерности для любого идеологического воздействия.

С позиций «логической социологии» А.А. Зиновьев предлагает изучать и культурно-исторические предпосылки того или иного явления. Чтобы лучше понять изучаемые процессы, имеющие свою историю, их лучше всего изучать в развитом состоянии и уже исходя из него, рассматривать их исторический генезис. Поскольку традиция такого изучения отсутствует, можно согласиться с тезисом А.А. Зиновьева о том, что первым шагом в изучении динамики социальных объектов становится здравый смысл, представленный в народной мудрости в виде пословиц, поговорок. Применительно к советской ментальности это могут быть пословицы и поговорки, в которых отражается устойчивое отношение представителей «народных низов» к тем или иным явлениям окружающего мира, к обществу, к самим себе. Для изучения менталитета советского общества особый интерес может представлять этот исторически сложившийся вид фольклорного творчества, в котором отражена тема социальной справедливости и любви к ближнему, ставшие основным «сюжетом» и «слоганами» идеологической пропаганды в обществе советского периода. Как пример - коммунистический лозунг «человек человеку - друг, товарищ и брат» можно оценивать как вариацию старой пословицы «Не имей сто рублей, а имей сто друзей».

Многое же в содержании социального знания, по мнению А.А. Зиновьева, может содержаться в языке той или иной исторической эпохи и в способах получения знания о ней. Конкретизируя это положение при изучении менталитета советского человека, можно обратить внимание на то, как на его формирование оказал влияние советский «новояз» с соответствующей пропагандистской терминологией и специфические способы получения знаний о реальности через формируемую коммунистической идеологией картину мира.

В соответствии с рекомендацией А.А. Зиновьева об однозначности определений изучаемых объектов, фиксирующих их устойчивые характеристики, в дальнейшем будут рассмотрены наиболее неизменные признаки советской ментальности независимо от произвольных ее трактовок тем или иным исследователем. Кроме того важно фиксировать и переменные в изучаемом социальном объекте в зависимости от тех и или иных реализуемых функций в рамках некоторого целого.

Причем, следуя открытому А.А. Зиновьевым методу восхождения от абстрактного к конкретному на примере изучения «Капитала» К. Маркса, необходимо выделить сначала наиболее общие («абстрактные») характеристики советского менталитета, а затем их все более конкретизировать, рассматривая проявления этого менталитета в разных социальных и исторических ситуациях. Именно эти методические подходы были использованы при изучении культурно-исторических предпосылок формирования менталитета советского народа.

\section{Результаты}

В соответствии с предложенной выше методикой этот менталитет выявлялся исходя из того, что он не появился как результат только влияния отдельных политических лидеров или даже узкой группы лиц (например, 
большевиков), но явился еще и результатом социального творчества масс. Главным признаком этого менталитета являлось стремление к коллективизму как образу жизни и норме социальных взаимодействий во всех сферах жизнедеятельности общества. Причем, это стремление имело большую историческую традицию $[7,17]$.

Как отмечает известный исследователь советского общества С.Г. Кара-Мурза, стремление к коллективности в русском народе наблюдалось на протяжении всей его истории $[11,12]$. Оно стало устойчивой характеристикой менталитета русских людей после принятия христианства, сформировавшего религиозно-общинный уклад жизни в качестве господствующего. В качестве главной духовно-нравственной установки в этом укладе стала заповедь любви к ближнему как к самому себе.

На первый взгляд может сложиться впечатление, что в советском обществе не свойственно было проявлять особую душевность в отношениях с ближними, поскольку на первом месте стояло служение коллективу и государству. И ради этого стоило жертвовать многими межличностными отношениями. Но здесь следует иметь в виду, что коллектив в советском обществе был основной его ячейкой и определял все стороны жизни его членов, включая личную жизнь. Большинство советских людей добровольно приняли эту роль коллектива, потому что последний одновременно проявлял заботу о его членах, гарантировал определенный уровень жизни, социальные блага и гарантии. Заповедь любви к ближнему здесь реализовывалась через реальную взаимопомощь и солидарность в процессе служения общему делу.

Идея коллективности получила в советский период невиданный размах и на уровне общества, что выразилось в принятии большинством членов этого общества тезиса - «сложилась новая историческая общность - советский народ». Тем самым была принята большинством членов общества личностная самоидентификация в качестве советского человека, оказавшаяся даже более значимой, чем отнесение себя к тому или иному этносу, национальности.

Традиционная особенность менталитета русского народа в виде готовности служения ближнему проявилась через отказ от частной собственности как главной причины эксплуатации трудящихся. Коллективизм как образ жизни воспринимался в качестве альтернативы, устраняющей причины этой эксплуатации. Совмещение в советском обществе этой религиозной заповеди в виде стремления оказывать помощь не только ближним, но и «дальним» выразилось в т.н. пролетарском интернационализме, борьбе с колониальными режимами, что также имело свою историю - готовности России на протяжении своей истории помогать тем или иным жертвам несправедливой экспансии, угнетения и т.д. Об этой осо- бенности менталитета русского народа писал еще Ф.М. Достоевский, добавляя при этом, что желание оказывать помощь другим народам не всегда было оправданным [5].

Еще одной исторической традицией, определившей на века ментальность русского народа, стала сакрализация им государственной власти и своих правителей. Верноподданический инстинкт оказался достаточно привычным для психологии основной массы населения с первых лет Советской власти, что выразилось в обожествлении руководителей государства до периода «хрущевской оттепели», прервавшей эту традицию. Не случайно в этой связи отнесение Н. Бердяевым создателя страны Советов В.И. Ленина к галерее самодержцев, существовавших в истории России [1]. Характерно, что эта традиция была позже возобновлена и в постсоветской России. Государственная власть в российском обществе чаще всего была персонифицирована в лице конкретного главы государства, с которым народ связывал свои основные чаяния и надежды, даже если власть, так или иначе, себя дискредитировала. В последнем случае существовал устойчивый стереотип - «царь хороший - бояре злые».

Характерно, что, когда в «брежневский» период была разрушена традиция преклонения перед первым лицом государства, которое становится персонажем «нового фольклора» в виде соответствующих народных анекдотов, началось и постепенное разложение власти как таковой с последующей «десоветизацией» и «декоммунизацией» российского общества.

Пиетет каждого члена советского общества перед государством явился сохранением такого проявления религиозно-общинного начала как служение «своему» господину (в досоветский период - в первую очередь своему «барину» т.к. большинство жителей дореволюционной России были крестьянами, приписанными к тому или иному помещику).

При этом на протяжении веков основная масса жителей России мечтала о лучшем будущем, что выразилось в соответствующих произведениях фольклора, в периодически возникающих бунтах и крестьянских восстаниях. В советском обществе эта традиция борьбы за лучшую долю своеобразно переплелась с религиозной верой построения «рая на земле», получившего название коммунизма. Сложился особый тип религиозного сознания советского человека, предпочитающего строить самому будущее общество справедливости и взаимопомощи, без надежды на помощь «свыше» от небесных сил. Соответственно насаждаемый воинствующий атеизм являлся оборотной стороной этой религиозной установки. Сам же коммунизм воспринимался как создание традиционной общинности высшего уровня с его принципом «от 
каждого по способностям - каждому по потребностям».

\section{Обсужкение}

В изучении культурно-исторических предпосылок формирования менталитета советского народа важная роль принадлежит одному из ведущих исследователей советской цивилизации С.Г. Кара-Мурзе $[11,12]$. Полученные им результаты позволяют осмыслить некоторые существенные особенности этого формирования.

Так, этот ученый отмечает, что советское государство впервые продемонстрировало всему миру возможность существования общества без «избранных» и «отверженных». И в этом состояла одна из причин законной гордости советских людей за свою страну, ставшей привычной для их самосознания. Советский проект, как справедливо отмечает С.Г. Кара-Мурза, был евразийским проектом. Это выразилось в том, что европейская версия марксизма не была принята большевиками и советским народом потому, что для этого отсутствовали объективные предпосылки в виде длительного противостояния пролетариата и буржуазии, а также культа индивидуализма $[4,15,20]$, которые имели давнюю историю в Европе, как и устоявшиеся легитимные формы этого противостояния. Азиатская же психология, проявившаяся в русском народе и перешедшая по наследству в советское общество, состояла в ориентации на сильную власть, подчиненности государству как высшей социальной ценности. В результате советский человек сохранил в себе многие черты традиционного русского характера, описанного еще Н. Бердяевым: «русский народ с одинаковым основанием можно характеризовать, как народ государственно-деспотический и анархически-свободолюбивый...» [1].

Основной же движущей силой социалистической революции являлось крестьянство с его религиознообщинной психологией и тягой к соборности. Это наложило свой отпечаток и на формирование советского менталитета, где роль отдельной личности, тех или иных меркантильных интересов в борьбе за свои права уступила, в конечном счете, стремлению к общественному и государственному служению, которое определяло психологию русского народа до революции $[2,19]$.

Еще одной ментальной особенностью советского народа, унаследованной от дореволюционного прошлого, являлось отношение к созидательному труду как главной жизненной ценности. Жизнь русского крестьянства, составлявшего 90\% населения России, носила трудовой характер, необходимый для его физического выживания. В результате сформировалась психология трудового человека, которая органично вошла в менталитет советского народа. В советском обществе трудовой образ жизни считался почетным, а людей, уклоняющихся от труда считали тунеядцами. Такая позиция имела и свои издержки, главной из которых было подозрительное отношение к представителям творческих профессий, связанное с высокой престижностью физического труда как наиболее значимого в обществе с недостаточно развитой технологической базой производственной деятельности [6].

При этом моральные стимулы к труду воспринимались как более значимые в сравнении с материальными, что можно также считать развитием религиозно-общинной традиции «бессеребренничества» и «нестяжательства», которые всегда являлись одним из показателей праведности еще в Древней Руси.

Относительное полное представление о менталитете советского народа может быть получено на основе сопоставления характеристик советского человека (в терминологии А.А. Зиновьева - «коммуноида») $[8,13]$ и среднего европейца (в его же терминологии, названного «западоидом»). Отталкиваясь от зиновьевских характеристик «западоида», можно предложить следующее его сопоставление с советским человеком («коммуноидом»):

\begin{tabular}{|c|c|}
\hline $\begin{array}{c}\text { Повышенная склонность } \\
\text { к индивидуализму }\end{array}$ & $\begin{array}{c}\text { Повышенная склонность } \\
\text { к коллективизму }\end{array}$ \\
\hline Изобретательность & Склонность к подражанию \\
\hline Практицизм & Идеализм \\
\hline Деловитость & Беспечность \\
\hline Расчетливость & Нерасчетливость \\
\hline Авантюристичность & Сдержанное отношение к аван- \\
\hline тюрам
\end{tabular}

Таким образом, речь идет о во многом несовместимых культурно-антропологических различиях [10], которые нельзя не учитывать при изучении особенностей 
менталитета советского народа.

\section{Зак^ючение}

Рассмотрение менталитета советского народа позволяет сделать вывод о наличии объективных культурноисторических предпосылок формирования психологии советских людей, которая не являлась только результатом целенаправленной коммунистической пропаганды. Именно потому, что пропагандистское воздействие попадало на благодатную почву религиозно-общинной традиции в повседневном образе жизни русского народа, оно имело значительный социально-политический и культурно-воспитательный эффект.

В менталитете советского народа, кроме того, поми- мо особенностей, значимых для конкретного исторического периода, присутствовали характеристики, не потерявшие своего значения в наши дни. Среди них можно выделить: готовность связывать основные жизненные цели и смыслы со служением своему народу и своей стране; ценности коллективизма (при условии уважения к индивидуальности каждого члена общества); трудолюбие, патриотизм вплоть до реального самопожертвования, если это связано с благом и существованием своей Родины; вера в возможность построения справедливого общества и основанный на ней социальный оптимизм; активная жизненная позиция, выражающаяся в неравнодушии к проблемам общества и других людей как альтернатива мещанской и обывательской психологии с ее ценностями консюмеризма и животного благополучия.

ЛИТЕРАТУРА

1. Бердяев Н.А. Истоки и смысл русского коммунизма. - М.: Наука, 1990. 223 с.

2. Бердяев Н.А. Русская идея. - СПб.: Азбука, Азбука, Аттикус, 2012. 320 с.

3. Воеводина Л.Н. Мифология и культура. - М.: Институт общегуманитарных исследований, 2002. 384 с.

4. Гоббс Т. Левиафан. - М.: Мысль, 2001.478 с.

5. Достоевский Ф.М. Избранное. - М.: Изд-во Сретенского монастыря, 2002. 400 с.

6. Зиновьев А.А. Зияющие высоты. - М.: Эксмо, 2008.756 с.

7. Зиновьев А. Коммунизм как реальность. - М.: Центрполиграф, 1994.495 с.

8. Зиновьев А. Мой дом - моя чужбина. Гомо советикус. - М.: приложение к журналу «Лепта», 1991.320 с.

9. Зиновьев А. На пути к сверхобществу. - СПб.: изд. дом «Нева», 2004. 608 с.

10. Когатько Д.Г., Тхакахов В.Х. Российская идентичность. - СПб. Алетейя, 2010. 250 с.

11. Кара-Мурза С.Г. Советская цивилизация (книга первая). - М.: Алгоритм, 2001.528 с.

12. Кара-Мурза С.Г. Советская цивилизация (вторая). - М.: Алгоритм, 2001.688 с.

13. Кьеза Дж. Прощай, Россия. - М.: Изд-во «Гея», 1998. 272 с.

14. Лосев А.Ф. Диалектика мифа. - М.: Академический проект, 2008. 303 с.

15. Макиавелли Н. Государь. - М.: Мысль, 1996.639 с.

16. Розин B.M. Теория культуры. - М.:NOTA BENE Медиа Трейд Компания, 2005. 416 с.

17. Селезнева Е.Н., Каменец А.В. Культурология Русского мира: духовные основы национального менталитета. - М.: «РИТМ», 2013.432 с.

18. Феномен Зиновьева. Сост. Гусейнов А.А., Зиновьева 0.М., Кантор К.М. - М.: изд-во «Современные тетради», 2002.400 с.

19. Хомяков А. Всемирная задача России. - М.: Институт русской цивилизации; Благословение, 2011. - 784 с.

20. Шпенглер 0. Закат Европы. Очерки морфологии мировой истории. Т.1. - М.: Мысль, 1993. - 663 с.

( ) Каменец Александр Владленович (kamenez.a@rambler.ru), Ковалёва Инна Алексеевна (in_kov19@mail.ru).

Журнал «Современная наука: актуальные проблемы теории и практики» 